\title{
POLSKO-UKRAIŃSKA KONFRONTACJA PODCZAS POLSKO-UKRAIŃSKIEJ WOJNY 1918-1919
}

\author{
Yevhen Lyzen \\ Postgraduate Student at the Department of Word History, \\ Precarpathian National University named after Vasyl Stefanyk, Ukraine \\ e-mail: luge82@ukr.net,orsid.org/0000-0002-3621-5922
}

\section{Streszczenie}

W artykule analizowane polsko-ukraińsku konfrontacju podczas polsko-ukraińskiej wojny 1918 - 1919 r. Stwierdzono, że okres rekonwalescencji państw narodowych Ukrainy i Polski, to opis generowany w czasie Pierwszej wojny światowej i Ukraińskiej rewolucji, zajmuje znaczące miejsce w losie polaków zachodnio-ukraińskich ziem. Rozwiązanie "ukraińskiego" i "polskiego" pytań, tworzenie niepodległych państw sąsiednich narodów słowiańskich odkrywał szansę do budowania nowej architektury Europy Środkowo-Wschodniej, jednak ono natknęło się na stereotypy imperialnej polityki Rosji i państw zachodnich, długotrwałe sprzeczności między ukraińcami i polakami, w centrum których znaleźli się roszczeń terytorialnych Polski na Wschodnią Galicją i Zachodnią Wołyń.

Polityka URL (Ukraińska Republika Ludowa) stosunkowo polskiego etnosu w dużej mierze zależy od stosunków międzypaństwowych z przywróconym jesienią 1918 r. Polskim państwem. Skomplikowane, a czasami i wrogie stosunki między Polską i URL negatywnie odbijały się na sytuacji polskich mieszkańców Wołynia i Podola. Ponadto wśród ukraińskich partii politycznych i organizacji wojskowych nie było jednolitego stanowiska w odniesieniu do ludności polskiej.

Słowa kluczowe: Polska, URL, ZURL (Zachodnioukraińska Republika Ludowa), UGA (Ukraińska Halicka Armia), konfrontacja, Polsko-ukraińska wojna, URN (Ukraińska Rada Narodowa).

DOI https://doi.org/10.23856/4312

\section{Wprowadzenie}

Dzisiaj, biorąc pod uwagę doświadczenia z przeszłości, Polska jest zainteresowana w istnieniu niepodległej Ukrainy, która jest gwarantem tego, że polskie wschodnie granice, a to oznacza, że wschodnia granica Unii Europejskiej nie zamieni się w strefę niepewności. Z kolei Ukraina widzi w tym przyjaznym kraju sąsiada najbliższego oddziału partnera, związek z których jest traktowany jako regionalny czynnik stabilności.

Niemniej jednak, pomimo dużych zmian na poziomie stosunków międzypaństwowych, ukraińsko-polskie stosunki środkami poziomie pozostają na bardzo ograniczonym poziomie. Do tego czasu zarówno w polskim, jak i w społeczeństwie ukraińskim, żyją wzajemne historyczne stereotypy w stosunku do siebie. I nie jest to zaskakujące, ponieważ wspólna historia zawsze rodzi stereotypy i mity, zarówno pozytywne, jak i negatywne. Główną przyczyną zakorzenienia tych stereotypów, zdaniem wielu badaczy, jest wyraźne i głośne przegub nacjonalistów obu państw na historycznych krzywd, że zadali przedstawiciele innego. I jeśli dziś zarówno w ukraińskiej, jak i polskiej historiografii dużo się pisze o wzajemnych stereotypach, odbywają się liczne międzynarodowe konferencje, gdzie mówi się również o wzajemne przeprosiny, jednak te stereotypy pozostają na poziomie socjologicznym bardzo odporne. 


\section{Okres odbudowy państw narodowych}

Podsumowanie materiału podstawowego badania. Obalenie caratu w wyniku rewolucji Lutowej 1917 r. i początek demokratyzacji państwa Rosyjskiego został pozytywnie przyjęty zdecydowaną większością polaków. Przychylnie odniosła się polska społeczność Ukrainy do tworzenia i pierwszych kroków działalności Centralnej Rady Ukraińskej (CRU). Ogłaszając w pierwszych zamówiłem prawo ukraińców być gospodarzami na swojej ziemi, CRU zgłosiła jednocześnie prawo do zatrudnienia warstw nieukraiński (polskiego, żydowskiego...) ludności na zaspokojenie swoich narodowo-kulturowych potrzeb. Przywódcy najważniejszych ukraińskich partii politycznych podzielali popularne w Europie Zachodniej idei narodowo-osobistej autonomii. Właśnie CRU i jej prezes głowa M. Gruszewski po raz pierwszy w ukraińskim życiu społeczno-politycznym ruchu wypracowali program zapewnienia praw politycznych wszystkich etnicznonarodowy społeczności w URL, zaspokojenia ich kulturowo-narodowych, religijnych i innych potrzeb (Reient, 2016: 257).

Głoszenie ZURL w wymiarze czasowym zbiegło się z odzyskaniem niepodległości państwowej Polski, rząd który ogłosiłem na powrót do granic Pierwszą Rzeczą Rzeczypospolitej 1772 r. To głównie spowodowało ostry międzyetniczny konflikt, który przerodził się w polsko-ukraińską wojnę listopada 1918 r. - czerwca 1919 r., znacząco wpłynął na funkcjonowania miejscowych polaków, z których znaczna część dołączyła do zasilanego rozdzielczości etnicznoterytorialnych problemów (Vasiuta, 2006: 15).

Za cztery wieki pobytu Galicji w składzie Polski, a później Austrii i Austro-Węgierskiej imperiów, skład etniczny ludności krawędzi przeszedł duże zmiany, ale ukraińcy jak awtohtony i dalej pozostawały największej grupy etnicznej. Przypomnijmy, że nawet przy daleko stronnicze według austriackiego spisu ludności z 1900 r., w Galicji Wschodniej mieszkało 3,6 mln. greko-katolików (głównie polacy - 22,7\%), 614 tys. żydów (13\%). Za język komunikacji wydana ludność wynosiła 2,9 mln osób, polskojęzyczny - 1,5 mln. niemieckojęzyczny 175 tys (Makarchuk, 1997: 14-16). Nawet w tej statystyce co najmniej dwie trzecie mieszkańców krawędzi stanowili ukraińcy. Ponadto należy mieć na uwadze, że sporo ukraińców pod naciskiem okoliczności zmieniły rodzica, pochodzenie etniczne i wiarę w polską i kościół rzymsko-katolicki, czyli ich ukraińska tożsamość mogła być aktualizowana. Inaczej mówiąc, na początku XX wieku. Galicja pozostała ukraińskim krawędzią, a centrami idei narodowej, ukraińskiego życia kulturalnego i politycznego były miasta, przede wszystkim Lwów, chociaż ukraińcy stanowili w nim mniejszość.

Należy jednak pamiętać, że na przestrzeni wieków polska propaganda starała się kształtować w społeczeństwie opinia o Zachodniej Ukrainie jako odwieczne ziemie polskie lub Małopolska. Ten pomysł broniła większość przywódców polskiego ruchu narodowo-wyzwoleńczego po znanych rozbiorów Polski, uruchamiania z niej odrodzenia państwa Polskiego w tzw. "historycznych granicach" z włączeniem "polskiego Lwowa" i "południowo-wschodniej Małopolski”. Jeśli liderzy polskich narodowych demokratów w ogóle nie uznawali za ukraińcami publiczno-twórczych potencjałów, to polscy socjaliści J. Piłsudskiego mówili o możliwości federacji z Ukrainą, ale nie wyraził swoje stanowisko w sprawie jej statusu i granic.

Bezpośrednim impulsem do procesów tworzenia na terenie Galicji i nawiewów konfrontacji ukraińców i polaków stał się Manifest cesarza Niemiec Wilhelma II i Austro-Węgier Franciszka Józefa od 5 listopada 1916 r., w którym zdeklarowany tworzenie na podrosyjski ziemiach Polski i Ukrainy Królestwa Polskiego jako "samodzielnego" państwa z dziedziczną monarchią, konstytucyjnym ustrojem i armią. Przez 10 dni rząd Rosji przyznał ten manifest nieważne, ale obiecał polakom autonomię w ramach imperium. W styczniu 1917 r. w Warszawie powstała 
Tymczasowa rada państwa, na którą zostało ogłoszony formowanie sił zbrojnych Królestwa, które miały wystąpić na jego ochronę (Zashkilniak, Krykun, 2002: 439).

Kontrowersyjna była reakcja polskich czynników na tajne warunki Brześćkych umów 1918 r., za którymi Austro-Węgry zobowiązała się włączyć do końca lipca 1918 r. Galiciją Wschodnią i południową Bukowinę na jedyny krawędź korony, a Chełmszczyna i Podlasie zostały odejść do URL. Niestety, hetmańskim przewrót zerwał się na ten plan, a austro-węgierski rząd wycofał się ze swoich zobowiązań, ponieważ przedstawicielom Ententy ukraiński pytanie został złożony jako "austro-węgierska intryga". W tak trudnej sytuacji jesienią $1918 \mathrm{r}$. zaktywizowali krajowe jazdy za stworzenie ukraińskiej i polskiej państwowości, co wynikało z manifestu cesarza austriackiego Karola od 16 października 1918 r., w którym przetrzymywany jest wezwanie do narodów monarchii założyć własne państwa i wejść w nowy federalny stan. Wspólne dla obu ruchów było dążenie ukraińców i polaków do samodzielnego narodowo-kulturalnego rozwoju, odbudowy państw narodowych, do oderwania Galicji od Austro-Węgier, ale dalszy jej rozwój był diametralnie przeciwny. Jeśli czołowe ukraińskie partie polityczne mącił perspektywy Galicji jako części przyszłego samodzielnego państwa Ukraińskiego, to większość polskich politycznych, stowarzyszeń traktowali ją jak "kresy wschodnie" odnawialnej Rzeczy Rzeczypospolitej.

\section{Nowa faza konfrontacji polsko-ukraińskiej}

Nowa faza polsko-ukraińskiej konfrontacji rozgrywała się na tle zmiany paradygmatu i głębokich pęknięć zarówno w polskim, jak i ukraińskim krajowych ruchach, gdzie oglądano przeciwne cele. Wraz ze zwolennikami sojuszu z Austrią było nie mniej modulatorów i sympatycy idei autonomii w składzie demokratycznej Rosji. Coraz częściej mówili o sobie zwolennicy ruchu wyzwoleńczego, siłowej walki o pełną niepodległość Ukrainy i Polski, tworzenie podziemnych oddziałów zbrojnych, które w warunkach wojny odgrywały kluczową rolę w odbudowie narodowej państwowości (Lypovetskyi, 2018: 180).

Na związek ukraińców i polaków negatywnie wpływały stare urazy i zniewagi, odziedziczone z czasów polskiej kolonizacji ukraińskich ziem i wojny Wyzwoleńczej narodu ukraińskiego środku XVII wieku, ambitne stereotypy wyższości polskiej szlachty w stosunku do ludności ukraińskiej, która, ze swej strony, zakłada niesprawiedliwe naruszenia krajowych praw. Jednak w świadomości części wiodącego warstwy polaków i ukraińców wykiełkowane zrozumienie, że tylko wspólnym wysiłkiem można złamać imperialne kajdany, osiągnąć wolność i niezależność i przywrócić państwa narodowe. Jednak w polskiej społeczności Galicji i Wołyni górę brali szowinistyczne i konfrontacyjne nastroje, wzmocniony w warunkach narastania narodowo-wyzwoleńczych zawodów, zdetonowane Pierwszej wojny światowej i kryzysu cesarskich trybów.

Polacy, w przeciwieństwie do ukraińców Galicji, bardzo chłodno przyjęli utworzenie CRU, jej III i IV Uniwersale o ogłoszeniu URL i jej samodzielności. Z entuzjazmem powitali galicyjskie ukraińcy udział delegacji z Ukrainy w obwodzie Brześckej konferencji pokojowej, jej definicja o włączeniu Podlasia i Chełmszczyna w skład URL, czego nie można powiedzieć o reakcji polskich шовинистических kręgów, które deklarowały, że Brześcka umowa narusza wschodnie granice Królestwa Polskiego i jest "czwartym rozbiorem Polski”.

Starając się osłabić ukraińskie i polskie krajowy ruch, wbić klin w stosunki jego przywódców, Tymczasowy rząd w Petersburgu przyznał prawo narodu polskiego do niepodległego państwa, którego pomysł poparły rządy Stanów Zjednoczonych, Francji, Anglii i Włoch. Później prawo polskich robotników do niepodległej państwowości zostało ogłoszone przez rząd 
bolszewickiej Rosji. Propolskie oświadczenia rządów Rosji i krajów zachodnich stały się swoistą kartą Rady Regentów, utworzoną we wrześniu 1917 r., w celu zwołania wyborów do Sejmu, a tym samym powołania w Krakowie Polskiej Komisji Likwidacyjnej w celu oddzielenia Polski od Rosji i przejęcia władzy od Austro-Węgier w Galicji. W takich warunkach Polacy regionu znaleźli się w epicentru polsko-ukraińskego sprzeciwu, która stała się konfrontacyjna. Główną przyczyną była próba przywódców polskiego ruchu państwowego włączenia Ukrainy Galicji i Wołynia Zachodniego do Polski.

Jednocześnie ignorowano naturalne prawo Ukraińców regionu do samostanowienia, tworzenia własnej państwowości i kroki podejmowane w tym kierunku, ponieważ 18 października 1918 r. Ukraińska Reprezentacja parlamentarna zwołała Zgromadzenie Konstytucyjne we Lwowie i ogłosili powstanie własnej państwowości. Następnego dnia URN (Uraińska Rada Narodowa) ogłosiła utworzenie państwa ukraińskiego we Wschodniej Galicji, Bukowinie i Zakarpaciu. Należy podkreślić, że URN gwarantowała zapewnienie praw politycznych i narodowo-kulturalnych mniejszości w państwie ukraińskim - Polakam, Żydam, Niemcam, Węgram, Czecham i innym (Lytvyn, 2015: 69).

Polska Komisja Likwidacyjna pod przewodnictwem V. Vitasa, któremu tymczasowo powierzono funkcje władzy w Galicji, planowała przybycie do Lwowa w dniach 1-2 listopada 1918 r. Biorąc pod uwagę tę okoliczność, a także fakt, że generalny gubernator Galicji K. Guin odmówił przekazania władzy na Ukrainę reprezentacja, w nocy 1 listopada ukraińskie jednostki lwowskiego garnizonu armii austriackiej i legion ukraińskich strzelców pod dowództwem D. Witowskiego w objął instytucje rządowe, przejął stację kolejową, pocztę, magistrat i inne. Rano niebiesko-żółta flaga została podniesiona nad lwowskim ratuszem, a apele URN naklejone na ścianach domów zapowiadały narodziny państwa ukraińskiego na ukraińskich ziemiach etnicznych byłych Austro-Węgier.

Sytuacja we Lwowie skomplikowane tym, że ponad 62\% jego mieszkańców stanowili polacy, 20\% - żydzi i tylko 18\% - ukraińcy (Kalakura, 2007: 137). Do tego brakowało jedności ukraińskich narodowo-demokratycznych sił w podejściu do ukraińskiej państwowości, z których część była na Wiedeń, kursy rewolucyjnych deklaracjami, zwlekała z formowaniem rządu ZURL, nie zadbała o wzmocnienie Ukraińskiej Galicyjskiej Armii (UGA), utworzonej w listopadzie 1918 r., co było na rękę Polsce. Tylko 9 listopada URN utworzyła Tymczasowy sekretariat stanu, a 10 listopada wypowiadała się na spotkanie z państwem Ukraińskim na Wschodzie i kazała zacząć odpowiednie negocjacje. Choć oficjalne przekazanie władzy od cesarskiego namiestnika do Ukraińskiej narodowej rady odbyła się, ale jej prawdziwy rozwój natknąć się na opór miejscowych polaków, kupując szczególną ostrość w Lwowie i na zachodniej granice, w szczególności w Przemyślu, wokół którego wybuchł prawdziwy ogień polsko-ukraińskiej wojny. Na początku listopada 1918 r. w Lublinie rozpoczęło się formowanie rządu Tymczasowego Polskiej Republiki Ludowej, który w swoim manifeście zadeklarowała polską władzę na wszystkich "historycznych ziemiach", w tym Galicja. Natomiast 13 listopada UNRada ogłosiła Tymczasowe podstawowe prawo, które oficjalnie ogłaszała Zachodnio-Ukraińska Republika Ludowa (ZURL). I do tego czasu polskie polityczne i wojskowe organizacje już udało się zorganizować i przejść do ofensywy, aby uniemożliwić zatwierdzenie ZURL, zapewnić przyłączenie Lwowa i Galicji Wschodniej, a następnie i Zachodniego Wołynia odzyskanej Polski.

Chociaż roszczenia polskich polityków do Galicji Wschodniej były sprzeczne z "14 punktami” pokoju w Europie, ogłoszonymi przez prezydenta USA W. Wilsona, zgodnie z trzynastym punktem, państwo polskie miało się zregenerować w populacji polskiej, a także w Galicji Wschodniej, Hełmskiej, Podlaskiej, na Wołyniu Zachodnim Ukraińcy znaleźli szerokie poparcie ze strony lokalnych Polaków. Ponadto polskim władzom udało się szybko utworzyć jednostki 
wojskowe z miejscowych Polaków, przenieść dodatkowe siły z Krakowa, Warszawy i innych miast oraz rozpocząć krwawe bitwy o Lwów. Wojna z ukraińcami o Lwów była postrzegana jako przejaw polskiej tradycji narodowej, jako symbol patriotyzmu. Podstawą polskich formacji wojskowych były oddziały Polskiej Organizacji Wojskowej, Polski Korpus Pomocniczy oraz polski personel wojskowy, którego generalnym kierownictwem był Cz. Monczyński. W zażartych bitwach o Lwów, które rozpoczęły się 1 listopada 1918 r. I trwały z różnym powodzeniem do 21 listopada 1918 r., obie strony, w tym ludność cywilna, poniosły ogromne straty. Tylko dzięki przywódcom kościołów ukraińskiego i polskiego rozlew krwi został na chwilę zawieszony.

Pomimo udział miejscowych polaków w wojskowo-politycznej konfrontacji i poszukiwaniu dróg pojednania Polski i ZURL, wskazane jest, aby więcej się zatrzymać na tych wydarzeniach, aby dać odpowiedź na pytanie, dlaczego wygrali szowinistyczne siły, które udało się osiedlić we Lwowie, a następnie obalić ZURL. Dokumenty archiwalne, wspomnienia uczestników wydarzeń świadczą, że polacy na długo przed listopadowego zerwania prowadzili przygotowania do zasilanego zatwierdzeniu przez władze pod kierownictwem sztabu Generalnego Wojska Polskiego, kierowanego kadrowych generała T. Rozwadowskiego. Tworzył specjalną polską armię w Galicji pod dowództwem generała W. Sikorskiego, przypisane do wojskowego komendanta Lwowa A. Kamieński (Kuzma, 1931). Oprócz Lwowa, znaczne siły zbrojne polska władza koncentruje się w Stanisławie, Przemyślu, Kołomyji, Zoloczevi, Drohobyczu i innych miastach, równolegle prowadząc mobilizację cywilnej ludności polskiej. Należy podkreślić, że ukraiński przewód kontynuował poszukiwanie pokojowego rozwiązania konfliktu, zainicjował utworzenie wspólnego ukraińsko-polskiego komitetu, który w orędziu do polaków Lwowa tłumaczy prawo siłę proklamowania niepodległości państwa Ukraińskiego i gwarancji pełnego bezpieczeństwa polskiej miejski samorządu. URN zapewniła polaków i innych mniejszości narodowych "wolność używania w mowie, jak i w listach ich ojczysty mowy w rządowych stosunków z władzami państwowymi”. W swojej polityce wobec mniejszości narodowych ZURL nadala demokratyczne tradycje URL, poparła ją Ustawa o narodowo-osobistej autonomii. Takimi działaniami władza ukraińska nadzieję osiągnąć lojalny stosunek ludności polskiej do Republiki, ale nie znajdował właściwego zrozumienia z jego strony. Zdecydowana większość polskich nauczycieli, na przykład, nie złożyli przysięgi na wierność ZURL, ponieważ byli zwolennikami doktryny, według której "od wieków była i jest polska ziemia".

Ukraińscy i polscy przywódcy próbowali rozwiązać kwestię przynależności Lwowa poprzez dwustronny kongres pokojowy lub porozumienie międzyrządowe. Niestety społeczność polska zignorowała tę ofertę i nie okazała dobrej woli ustępstw i zrozumienia, preferowała siłę zbrojną i wznowiła działania wojenne. Każda ze stron próbowała wykorzystać krótkotrwały rozejm, aby uzupełnić swoje siły, aby kontynuować walkę.

21 listopada, po otrzymaniu potężnej pomocy od grupy “Odsecz” z Przemyśla, składającej się z 660 oficerów i 4900 żołnierzy, a także pociągu pancernego, oddziału powietrznego i broni, Polacy złamali zawieszenie broni, rozpoczęli ofensywę i zdołali przejąć centrum. Lwów i przejęcie kontroli nad niektórymi instytucjami. Następnie polskie jednostki wojskowe, opierając się na wsparciu miejscowej ludności polskiej, podjęły szereg prób umocnienia swojej władzy w innych miastach, w tym w Przemyślu, Samborze, Borysławe i Drohobycze, ale spotkały się z opozycją ukraińskich strzelców i miejscowej ludności.

Tak zakończyła się pierwsza faza polsko-ukraińskiej wojny. Obie strony poniosły duże straty: 300 zabitych i około tysiąca rannych ukraińców i prawie 1200 zabitych, rannych i jeńców polaków (Lytvyn, Naumenko, 1995: 68). Zwycięstwo polaków była spowodowana tym, że zregenerowana nimi państwo udać się szybciej konsoliduje się, utworzyć siły zbrojne, otrzymała realną pomoc państw Ententy. 
Polsko-ukraińska wojna, utrata Lwowa stały się jednym z czynników wyszukiwania przewodnikami ZUNR wsparcia ze strony Państwa Ukraińskiego P. Skoropadśky’ego. Jednak przeciw hetmanowi powstanie, podczas którego Dyrektoriat URL znalazła się w stanie wojny z bolszewicka Rosją i Białej armii, pozbawiony URL możliwości zaoferować praktyczną pomoc ZURL, którego rząd w końcu listopada został zmuszony przenieść się w Tarnopolu, a później do Stanisławowa. W takich warunkach stał bardziej złożony ukraiński soborniy proces, stłumiony działaniami wojennymi, które prowadziły obie ukraińskie państwa do konfrontacji: URL przeciw bolszewików i A. Denikina, ZURL - przeciw polskiej agresji. Podręcznik ZUNR położyć wielką nadzieję na połączenie z URL, ale nie wziął pod uwagę tę krytyczną sytuację, która rozwinęła się do Dyrektoriatu. W obliczu agresji bolszewickiej S. Petlura był zmuszony szukać pomocy u polskiego podręcznika, a znajdowało się w stanie wojny z ZURL.

W tym samym czasie 15 listopada 1918 r. zaczęło się pod wodzą Dyrektoriatu URL powstania przeciw hetmana P. Skoropadśky’ego. Dyrektoriat zgłosiw swoją chęć przywrócenia zasady polityki Ukraińskiej Centralnej rady dotyczące mniejszości narodowych. 10 grudnia 1918 r. zatwierdziła uchwałę - przywrócić działanie prawa Centralnej rady z dnia 9 stycznia 1918 r. o narodowo-indywidualną autonomię. W tej uchwale, podjętej w Winnicy, było powiedziane, że "tymczasowo do odzyskiwania odpowiednich ministerstw należy ustanowić w Dyrektoriatu dział praw mniejszości narodowych”, który miał stanąć na czele były członek CRU, jeden z przywódców żydowskiej partii Poalei Syjonu S. Goldelman.

Według słów S. Goldelmana, ówczesny szef Dyrektoriatu W. Winnichenko siole miał duże wątpliwości, będzie pasował prawdziwe okoliczności czasu odzyskiwania ministerstw dla rosyjskiego i polskiego mniejszości, w wyniku czego ministrowie polacy lub rosjanie zajęli miejsca pełnoprawnych członków rządu URL. Istnienie tych stanowisk było widziane przewodniczącemu Dyrektoriatu przedwczesne. Rosjanie, jego zdaniem, nie czują się lojalni wobec URL, a uważali się raczej obywatelami Rosji. W odniesieniu do przywrócenia polskiej autonomii - należało poczekać do uregulowania kwestii praw mniejszości ukraińskiej w Polsce. Żydowska sam mniejszość, zdaniem przewodniczącego Dyrektoriatu, nie znajdowała się pod protektoratem ani jednego sąsiedniego państwa, dlatego list do hebrajczyków pozostało jedno skupić się na niepodległą Ukrainę (Ukrainska politychna emihratsiia 1919-1945, 2008: 37).

Naszym zdaniem, niechęć do Dyrektoriatu przywrócić narodowo-osobistej autonomii dla ludności polskiej URL można wyjaśnić następującymi głównymi przyczynami. Po pierwsze, w tym czasie, jak już wspomniano, rozpoczęła się walka pomiędzy armii UNR i polskiej armii za Zachodnią Wołyń. Ponadto, na terenie Galicji trwały działania wojenne między UGA i sił zbrojnych państwa Polskiego. Po drugie, część polskiej społeczności Prawobrzeżnej Ukrainy aktywnie włączyła się w proces odbudowy państwowości polskiej, a niektóre już nadzieję na przyłączeniu Podola i Wołynia do państwa Polskiego. Tak, w styczniu 1919 r. we wsiach Felshtyn, Kuriivka Proskurivskego powiatu zbrojna miejscowa ludność polska wystąpiło przeciwko URL. Prawda, wysłanego oddział karabinów maszynowych szybko i bez rozlewu zneutralizować to występ (Robitnycha hazeta, 1919).

Zbrojna konfrontacja towarzyszył wciągania miejscowej ludności polskiej na dużą skalę antyukraińskich akcji: udział w pogromach, masowe grabieże, aresztach, wyszukiwania, w zakazie ukraińskiej prasy, co wywoływało moje antypolskie nastroje. Odnotowano wiele świadectw o tym, że znaczna część ludności polskiej chwyciła za broń i faktycznie dołączyła do gwałtownych działań, nie traktowała apeli społeczności ukraińskiej do zrozumienia, prowokowała siłowej sposób rozwiązania konfliktu, który nabył etniczną barwę. Tymczasowe porażki ukraińców nie pokonało ich duch, ona tylko zaostrzyło długotrwały konflikt, przekonała się w potrzeby kontynuować walkę o narodowe prawa i własną państwowość. 
Polskie kręgi postawili przed sobą zadanie - postawić pod znakiem zapytania prawo narodu ukraińskiego na Prawobrzeżną Ukrainę. Przy tym ukraińcy byli traktowani tylko jak dzikusy i gajdamaci. Wśród miejscowego chłopstwa za darmo rozprzestrzeniała się literatura, która "uzasadnione" prawa Polski na Wołyń i Podole. Charakterystyczne jest, że taka postawa dzieliła nie tylko konserwatywnych polskimi działaczami, ale i demokratycznymi w kółko. Niektóre z nich w swoim czasie wspierał URL, ale po przywróceniu polskiej niepodległości zmienił swoje stanowisko w sprawie niepodległości Ukrainy. Naprawdę, tworzenie w tych warunkach polskiego ministerstwa mogło być legalne przykrywką do prowadzenia antyukraiński działalności. Po trzecie, Dyrektoriat i inne ukraińskie państwowe instytucje, musiał liczyć się z nastrojami ukraińskich partii politycznych i społeczeństwa, w którym panowały w tym czasie antypolski poglądy.

W tym samym czasie na ziemiach zachodnioukraińskich obok UGA przez cały powstawały bojowe oddziały Strzelców Siczowych, kozackiej kawalerii, toczyła się prawdziwa wojna partyzancka. W ciągu grudnia 1918 r. do stycznia 1919 r. działania wojenne były noszone głównie pozycyjny charakter: polacy próbowali za wszelką cenę utrzymać się we Lwowie, Naczelna Komanda UGA starała się go odeprzeć.

Pomimo działań wojennych, na kontrolowane terytorium ZUNR odbywało się szereg środków gwarantujących prawa mniejszości narodowych, w tym polaków, zaspokojenia ich potrzeb kulturalnych. Tak, w Ustawie o podstawach edukacji, przyjętym w dniu 13 lutego1919 r., było: “mniejszości narodowe mianowany prawo na szkoły w ojczystym języku”. W maju Sekretariat stanu edukacji i wyznania przyznał "prawo do ujawnienia” dowodów za wszystkie klasy Stanisławówskoj kobiecej gimnazjum z polskim językiem nauczania (Kalakura, 2007: 141).

Reakcja J. Piłsudskiego, w którego rękach skupiała się wojskową władzę, na działania zachodnich ukraińców była bardzo negatywna. On nie traktował państwowych inicjatyw ukraińców Galicji, ponieważ nie wyobrażałem sobie odnawialnej w Polsce bez tego terytorium. Polskie ludowe demokraci występowali z tak zwanej "program inkorporacyjny", która opierała się na idei "wybranymi” polaków, odnosiła ukraińców i białorusinów do "ludzi niższego gatunku”, które, jak mówią, nie mają tradycji państwowych. W przemówieniu na posiedzeniu Rady Najwyższej Ententy w końcu stycznia 1919 r. przedstawiciel Polski R. Dmowski mówił o intelektualną ukraińców i ich niezdolność utworzyć własne państwo, twierdził, że nie ma podstaw, aby wyjść Galicji Wschodniej.

Nawet gdy część polskiej polityki była świadoma niebezpieczeństwa bolszewizmu i celowości sojuszu z URL, który toczył wojnę z bolszewicką Rosją, ograniczając jej ekspansję na zachód, reakcję Polaków na walkę narodu ukraińskiego i przygotowanie traktatu jednoczącego ZURL. 3 stycznia 1919 r. w Stanisławowie URN zatwierdziła tekst „Traktatu przedakcesyjnego" i przyjęła rezolucję „W sprawie zjednoczenia Zachodnioukraińskiej Republiki Ludowej z Ukraińską Republiką Ludową" (Visnyk derzhavnykh zakoniv, 1919: 1). W odpowiedzi Dyrektoriat wydał Uniwersal URL w sprawie Unii z ZURL. Uroczysta proklamacja Aktu Zjednoczenia 22 stycznia 1919 r. na zatłoczonej radzie na placu Zofii w Kijowie stała się ważnym czynnikiem moralnym w obronie sprawy ukraińskiej, ale została negatywnie odebrana przez ludność polską nie tylko w Galicji, ale także w regionie Dniepru. Jednocześnie niepokoiły go hasła socjalistyczne niektórych przywódców URL i ich gotowość do federalnego sojuszu z bolszewicką Rosją.

Mając Akt Zjednoczenia z URL, przywództwo ZURL w praktyce nie mogło uzyskać realne wsparcie Wielkiej Ukrainy, która sama potrzebowała pomocy wojskowej dla ochrony przed polsko-bolszewickiej agresji. Pojedynek Galicji z Polską przekształcił się w daleko w 
nierównej siły na wojnę z Ententą. Straty, które poniosła URL ze strony armii Czerwonej, pociągnęli za sobą i porażka UGA na polskim froncie. Wkrótce po Akcie Zjednoczenia działania wojenne zostały wznowione, rozpoczął nową ofensywę UGA, znany pod nazwą "Wołczuchowska operacja”, po której ukraińcy umocniły się na dogodnych pozycjach w pobliżu wsi Wołwczuchy, zaznaczając kontrolę nad koleją na odcinku Gródok Jagielloński - Sądowa wisznia i przerwał połączenie polakom ze Lwowem. W czasie, gdy ukraińcy byli bliżej do sukcesu, do Galicji przyjechała misja Entente, którą dowodził francuski generał Joseph Barthelemy. Sojusznicza misja miała zadanie rozwiązać polsko-ukraiński konflikt i przetłumaczyć sprawa przynależności państwowej Galicji na rozwiązanie Paryskiej konferencji pokojowej. Ceną pojednania musi być terytorialnego kompromis z obu stron (Hrytsak, 1996: 256). Na wniosek misji, oddziały ukraińskie powinny wycofać się za linię rzeki Bug do Kamionki Strumiłowej, dalej do Bóbrky i Nikołajewa, czyli tak zwaną "linię Barthelemy” (Kalakura, 2007: 143). Polsce odstąpił jedną trzecią terytorium Galicji Wschodniej, w tym Lwów i zagłębie naftowe. Nawiasem mówiąc, w tych negocjacjach z союзнической misji brał udział i Naczelny wódz URL S. Petlura, który znajdował się wówczas w Galicji Wschodniej. On skłaniał do wniosku J. Barthelemy, mając nadzieję, że Ententa uznaje URL-ZURL, a ukraińskie siły zbrojne po zawarciu rozejmu można użyć do wojny z bolszewicka Rosją. Jednak kierownictwo ZOURL (Zachodnia Obszar URL) rozważał proponowane warunki poniżające i odrzuciła plan Barthelemy (Stakhiv, 1959: 37). Taką jego reakcję można zrozumieć, ponieważ ani Polska, ani misja J. Barthelemy nie uznawali ZURL ignorowali interesy narodowe ukraińców. Wszystko to doprowadziło do tego, że tymczasowe zawieszenie broni na polsko-ukraińskim froncie (od 25 lutego do 1 marca 1919 r.) zostało przerwane. Chociaż, ukraiński historyk Iwan Lysiak-Rudnicki uważał, że propozycja Barthelemy była prawdziwym wyzwaniem dla rozwiązania polsko-ukraińskiego konfliktu. Przecież z jej przyjęciem ликвидировался front wschodni URL i główny ciężar walki tolerowany na Wschód, gdzie wojska Dyrektoriatu prowadzili zacięte walki z bolszewickiej Rosji.

Rozpoczął się nowy etap walki zbrojnej UGA za ukraińską ziemię. Był strzał szereg dzielnic Lwowa, zajęte jego okolicy. Szczególnie zacięte walki toczyły się w pobliżu k. Rawy Ruskiej i Żółkwi. Jednak, nie mając źródeł uzupełnienia sił, amunicji, ponosząc duże straty, zbrojne oddziały UGA wziąć Lwów nie udało się. Właśnie w tym czasie na pomoc lwówskemu garnizonu przybyła trzy tysiące operacyjny grupa z Poznania pod dowództwem D. Konashevskego, a także bataliony z Krakowa i Rzeszowa. Na żądanie Najwyższej Rady państw Ententy zostały wznowione negocjacje pokojowe, utworzona specjalna komisja pod przewodnictwem L. Boty do pojednania między ZUNR i Polską, ale polska delegacja celowo zwlekała z rozpoczęciem procesu negocjacyjnego, konsultacji dokumentów, aby wykorzystać czas na przygotowanie ostatecznej ofensywy wojskowej.

W kwietniu 1919 r. na polsko-ukraiński front było wywrócony dobrze uzbrojonych 80-tysięczną armię generała J. Galler, że znacznie zmienił się stosunek sił na korzyść Polski.

Najbardziej heroiczną próbą UGA chronić swoją Republikę stała się Czortkowska ofensywne operacja, która rozpoczęła się nieoczekiwanie dla polaków 7 czerwca 1919 r. Podczas niej była zniszczona, pancerna pod dowództwem W. Sikorskiego, zaczerpnięte Buczacz, Monastyrsk, Opłat, Berszad, Podgajcy, Tarnopol. Pojawiła się realna szansa, aby uwolnić całą ziemię Galicji i opanować Lwowem. Polacy stracili 156 żołnierzy, 1743 osób został ranny, 222 osób dostało się do niewoli (Krasivskyi, 2000: 137). Będąc w krytycznych warunkach, polacy ponownie zwrócili się o pomoc do armii J. Heller. Na front przybył J. Piłsudski i osobiście poprowadził kontratak, po otrzymaniu uprawnień Rady Najwyższej państw Ententy kontynuować operacje wojskowe w celu wyjścia na rzekę Zbrucz, co oznaczałoby okupacji 
Galicji. Opierając się na przewagę w sile militarnej i technice, polacy udało się zatrzymać ofensywę UGA, przejąć inicjatywę i już 15 lipca odeprzeć Tarnopol, wyjść na brzeg Zbrucza. Warto zauważyć, że w trakcie walk podczas Czortkowskej ofensywnej operacji delegacja URL, na czele generał-przez Siergiejem Delwigem, bez gruntownych konsultacji z kierownictwem ZOURL zawarła z Polską 16 czerwca 1919 r. "Umowa o czasowym wstrzymaniu ognia". Ale biorąc pod uwagę sukcesy na froncie, dowództwo UGA wstrzymało tu "Umowu" i kontynuował operację.

Pozostawiając z walkami Galicję Wschodniej, siły zbrojne UGA i dalej zadawały wymierne straty armii polskiej. 16 lipca 1919 r. UGA i przywództwo ZOURL przeniósł się do Kamieńca Podolskiego, gdzie był rząd URL i armia S. Petlury, nie tracąc nadzieję na powrót do Galicję. Na tej stronie kończyła się polsko-ukraińska wojna i działalność rządu ZURL na ukraińskiej ziemi, a dalej zaczynał się smutna strona jego екзильної historii i polityki dyplomatycznej. Jednak państwa zachodnie i USA w swoich podejściach do polskiego i ukraińskiego pytań na podstawie własnych interesów geopolitycznych, wykazywały sekciarstwo i niespójność. Wystąpienia poszczególnych западноукраинского państwa, polsko-ukraińska wojna wywołały u nich obawy co do stabilności powojennej Europy Środkowo-Wschodniej. Są one tendencję do idei "Wielkiej Polski", która miała powstrzymać ekspansję bolszewickiej Rosji. W tym samym czasie każda z państw zachodnich w polityce w odniesieniu do Galicji Wschodniej broniła własnych, przede wszystkim geopolityczne i gospodarcze interesy, które w większości nie pokrywają się z interesami ukraińców.

\section{Próby zrozumienia S. Petlury i J. Pilsudskiego}

Z końcem polsko-ukraińskiej wojny nastąpiła pewna stabilność, która miała miejsce w czasach tak zwanej Kamenets era (czerwiec-listopad 1919 r.), kiedy Kamieniec-Podolski na jakiś czas stał się głównym partnerstwa publiczno-centrum administracyjnym URL. Wtedy wydano szereg przepisów. Jednak autonomia dla ludności polskiej z Ukrainy i nie został przywrócony. Dzienniki URL i dalej kontynuowali drukować antypolski materiały. Tak, w rządowym "Biuletynie UNR" od 17 lipca 1919 r. została umieszczona adnotacja "Polski imperializm i Ukraina”. Jest w niej mowa o tym, że Polska nigdy nie odnosiła się przychylnie do Ukrainy, twierdził, że polska społeczność marzy o "Wielką Polskę" od "morza do morza”, a ktoś z polaków opowiadał się za koniecznością przystąpienia Kamieńca-Podolskiego do Polski.

Wkrótce jednak zawartość ukraińskich gazet nieco się zmienił. Naszym zdaniem było to związane z tym, że od sierpnia 1919 r. Naczelny wódz wojska URL i przewodniczący Direktoriat S. Petlura wraz ze swoimi najbliższymi współpracownikami pod wpływem politycznych niepowodzeń próbuje porozumieć się z kierownictwem Polski. Zwrócił się z osobistym listem do J. Piłsudskiego, w którym uzasadnił ideę konieczności wspólnej walki URL i Polski przeciw bolszewizmowi.

27 sierpnia 1919 r. Naczelny wódz URL w przemówieniu przed ukraińskim wojskiem podkreślił: "Zjednoczenie wszystkich sił demokratycznych wszystkich narodowości, które stały na glebę samodzielności naszej Republiki i udział ich w państwowym budownictwie będzie kluczem do naszego zwycięstwa nad wrogami i zadatkiem naszego samodzielnego i od nikogo niezależną życia" (Peliura, 1993: 143). Stąd można stwierdzić, że głowa Dyrektoriatu proponował i społeczeństwie polskim Prawobrzeżnej Ukrainy wziąć czynny udział w walce o niepodległą URL, gwarantując przy tym jej zaspokojenie krajowych potrzeb.

Członkowie rządu byli częściej słuchać lokalnych polskich organizacji. Tak, 26 sierpnia 1919 r. w Mohylewie Podolskim minister pracy URL W. Bezpalko podczas spotkania z 
przedstawicielami związków zawodowych, wśród których byli polacy, opowiedział się za koniecznością rozszerzenia zasad demokracji i narodowej autonomii (Robitnycha hazeta, 1919). Tym samym on zasugerował możliwość odzyskania danych z polskiej autonomii.

O stosunku ówczesnego rządu ukraińskiego socjal-demokraty I. Mazepy w polskiej społeczności można dowiedzieć się z artykułów wstępnych "Ukraina i Polska", opublikowanym oficjalnym czasopismem USDRP. W niej otrzymał wiele różni się od poprzednich charakterystyka polskiej społeczności Ukrainy. W szczególności podkreślano, że "wśród polskiego панства jest zobowiązanie do A. Denikina, bo program społeczny tego generała przyjemne dla polskich magnatów. Ale masy polskiej demokracji bez wątpienia odnoszą się wrogo do jednej Rosji". Zdaniem kierownictwa USDRP, całkiem możliwy był związek polskich polityków z ziemiaństwem-rosjanami do obalenia ukraińskiej państwowości. W tym momencie zauważyła gazeta, byłoby całkowitym szaleństwem próbować odzyskać Galicję. To by doprowadziło do wojny na trzech frontach: z bolszewikami, z Denikinym z Polską. "Naszym zdaniem, należy znaleźć wspólny język z Polską. Z uwzględnieniem politycznego momentu niedopuszczalne jest "zadzieranie" Polski...", - taki wniosek sprawia, że redakcja rządowej ukraińskiej partii (Robitnycha hazeta, 1919).

Późniejsze wydarzenia pokazały, że S. Petlura i J. Piłsudski nie udało się przekonać do celowości europejskiej swoich rodaków i współpraca ukraińsko-polska akcja nie stała się konsolidacja czynnikiem, ani na Ukrainie, ani w Polsce. Brak wzajemnie uzgodnione pozycji w ukraińskim kwestii pokazała Paryska konferencja pokojowa. Zniekształcanie informacji o skład etniczny ludności i charakter wydarzeń w Galicji, przewodniczący polskiej delegacji R. Dmowski próbował przekonać uczestników forum w nierozsądny uznania państwowości ZURL, interpretowane jej terytorium jak polski (Ripetskyi, 1963: 10). Stworzony konferencją specjalna komisja z polskich pytaniach poszła naprzeciw polakom i wypowiadała się za militarną presję na stronę ukraińską w celu zawarcia rozejmu i uznanie przyłączenia Lwowa do Polski.

Wspólna delegacja URL i ZOURL, ze swojej strony, protestowała przeciwko agresji Polski, wojskowej pomocy polakom, broniła uznania ZURL, interesów narodowych Ukrainy, zażądała wycofania obcych wojsk z terytorium Ukrainy, ale nie było jej słucha, ponieważ Polska, działając metodą "dokonanych faktów", już prawie była w posiadaniu terytorium Galicji. 25 czerwca 1919 r. Rada ministrów spraw zagranicznych Ententy uznał za Polską prawo do tymczasowego przeniesienia Galicji pod polskie zarządzanie w celu ochrony ludności cywilnej od bolszewików, pod warunkiem zapewnienia jej autonomii. Choć przedstawiciele wielkich mocarstw deklaratywnie twierdzili, że polacy nie mają prawa wprowadzać swoją władzę w Galicji Zachodniej i Wołynia, w rzeczywistości Polska konsekwentnie realizowała inkorporacji krawędzi. Ryski umowa zawarta pomiędzy Polską i trzech republik radzieckich - ZSRR, USRR i BSRR, nie położył kres ukraińsko-polskiej konfrontacji, ponieważ za jego warunków zachodnioukraiński ziemi w r. Zbrucz i Dniestr pozostawały poza Polską. On stał się dla polaków prawnym powodem dążąc do międzynarodowego uznania praw na Wschodnią Galicja i Zachodnią Wołyń.

\section{Wnioski}

W ten sposób, polsko-ukraińska konfrontacja 1918-1919 rr. miała wszystkie objawy wojny i zostawiła głębokie blizny na ciele obu narodów. Było to uwarunkowane procesem narodowego samostanowienia i utworzenia samodzielnych państw, w jej centrum znalazł się konflikt wokół niepodległości państwowej terenie Galicji Wschodniej i Zachodniej Wołyniu. 
Polacy i ukraińcy, przywracając swoje państwa, nie udało się porozumieć w sprawie roszczeń terytorialnych, uciekają się do mocy ich decyzji, co doprowadziło do polsko-ukraińskiej wojny, wielkich ludzkich, moralnych i materialnych strat z obu stron. Edukacja ZURL, łączenie jej z URL, sam Akt Zjednoczenia były negatywnie postrzegane polskimi wytycznymi w kółko i większością ludności polskiej, które nie mogły przezwyciężyć historyczne stereotypy w rodzaju "ukraińskiego zamachu" na ziemie polskie, "polskości Lwowa", wiecznośći "kresów wschodnich Polski" itp. Jak pokazuje doświadczenie historyczne, wojskowe zwycięstwo Polski nie miała perspektywy, ona jeszcze bardziej oddalony społeczeństwo polskie od zrozumienia praw i dążeń narodu ukraińskiego do samostanowienia i utworzenia państwa narodowego, wzmocniła szowinistyczny nastroje w środowisku polaków i spowodował odpowiedni protest ukraińców. Do starych skarg dodano nowe, które siały nieufność, pogłębiały napięcia międzyetniczne, zaprzeczały perspektywicznym interesom obu sąsiednich narodów, przyćmiły ich stosunki i znajdowały się w rękach sił trzecich. Polscy i ukraińscy historycy zgadzają się, że główną przyczyną konfliktu, w którym zginęło około 25000 Polaków i Ukraińców, był brak dobrej woli stron i ich zgody na ustanowienie uczciwych granic. Gorzkie doświadczenia z przeszłości pokazują, że stosunki między Polakami a Ukraińcami jako sąsiadującymi ludami słowiańskimi powinny opierać się nie na reanimacji wzajemnych krzywd, ale na szlachetnym haśle z 1920 r. „Za naszu i waszu wolność!”

\section{Bibliografia}

Vasiuta I. (2006) Politychna istoriia Zakhidnoi Ukrainy (1918-1939) [Political history of Western Ukraine (1918-1939)]. Lviv. [in Ukrainian]

"Visnyk derzhavnykh zakoniv i rozporiadkiv Zakhidnoi Oblasty Ukrainskoi Narodnoi Respubliky" [Bulletin of state laws and regulations of the Western Region Of the Ukrainian People's Republic]. (1919). [in Ukrainian]

Hrytsak Ya.(1996) Narys istorii Ukrainy: formuvannia modernoi ukrainskoi natsii XIX - XX st. [Essay on the history of Ukraine: the formation of the modern Ukrainian nation XIX-XX centuries]. Kyiv. [in Ukrainian]

Zashkilniak L., Krykun M. (2002) Istoriia Polshchi: Vid naidavnishykh chasiv do nashykh dniv [History of Poland: From ancient times to the present day]. Lviv. [in Ukrainian]

Kalakura O. (2007) Poliaky v etnopolitychnykh protsesakh na zemliakh Ukrainy u XX stolitti [Poles in ethnopolitical processes in Ukrainein the twentieth century]. Kyiv. [in Ukrainian] Krasivskyi O. (2000) Halychyna u pershii chverti XX st. Problemy polsko-ukrainskykh stosunkiv [Galicia in the first quarter of the twentieth century.: Problems pol.-ukr. relationships], Lviv. [in Ukrainian]

Krypiakevych I., Hnatkevych B. (1953) Istoriia ukrainskoho viiska. [History of the Ukrainian army]. Vinnipeh. [in Canadian]

Kuzma O. (1931) Lystopadovi dni 1918 r. [November days of 1918]. Lviv. [in Ukrainian]

Lypovetskyi S. (2018) Mech "Shcherbets" ta ukrainski vorota. [Sword "Scherbets" and the Ukrainian Gate.] Kyiv. [in Ukrainian]

Lytvyn M., Naumenko K. (1995) Istoriia ZUNR. [History of Western Ukraine]. Lviv. [in Ukrainian]

Lytvyn M. (2015) Proekt “Ukraina” Halychyna v Ukrainskii revoliutsii 1917-1921 rr., Kharkiv. [in Ukrainian]

Makarchuk C. (1997) Ukrainska respublika halychan: Narys pro ZUNR. [Ukrainian Republic of Galicians: an essay on the Western Ukraine]. Lviv. [in Ukrainian] 
Petliura S. (1993) Statti, lysty, dokumenty, Kyiv. [Articles, letters, documents]. [in Ukrainian] Reient O. (2016) Ukrainski vyzvolni zmahannia 1917-1921 rokiv. [Ukrainian liberation struggles of 1917-1921]. Kyiv. [in Ukrainian]

Ripetskyi S. (1963) Ukrainsko-polskyi protses 1918-1923 rr. [Ukrainian-Polish process 1918-1923]. Chykaho-Niu-York. [in American]

"Robitnycha hazeta". [Worker's newspaper]. (1919). [in Ukrainian]

Stakhiv M. (1959) Zakhidna Ukraina. Narys istorii derzhavnoho budivnytstva ta zbroinoi i politychnoi oborony v 1918-1923 rr. [Essay on the history of state building and armed and diplomatic defense in 1918-1923]. T. IV, Strenton. [in American]

Ukrainska politychna emihratsiia 1919-1945: Dokumenty i materialy (2008). [Ukrainian political emigration 1919-1945: Documents and materials]. Kyiv. [in Ukrainian] 